Joanna Pendzich', Wanda Maksymowicz-Mazur', Jolanta Pawłowska², Łucja Filipczyk², Ilona Kulawik ${ }^{3}$, Jerzy Zientek ${ }^{4}$, Jerzy Kozielski ${ }^{4}$

'Medical University of Silesia Public Teaching Hospital No. 3, Laboratory of Bacteriology and Tuberculosis

${ }^{2}$ Laboratory of Bacteriology, Hospital of Lung Diseases, Orzesze, Poland

${ }^{3}$ Laboratory of Bacteriology, Central Laboratory, Regional Health Centre, Katowice, Poland

${ }^{4}$ Medical University of Silesia, School of Medicine with the Division of Dentistry in Zabrze, Chair and Department of Lung Diseases

and Tuberculosis

\title{
Tuberculosis among the homeless and inmates kept in custody and in penitentiary institutions in the Silesia region
}

\author{
Gruźlica u osób bezdomnych i u osadzonych w aresztach śledczych oraz w zakładach \\ karnych województwa śląskiego
}

This study was financed by the Silesian Marshal's Office in Katowice within the Regional Tuberculosis Control Programme 2011-2014

\begin{abstract}
Introduction: There are more than 10 million prisoners in the world. Tuberculosis incidence is $10-100$ times higher in prisoners than in the general population. Inmates have close contact with other prisoners and with prison workers and visitors, so tubercle bacilli may be easily spread. Most of the inmates come back to normal life and contact with the general population.

The aim of the study was to assess active tuberculosis incidence among prisoners and homeless persons in the Silesia region.

Material and methods: In total 897 people entered the study, of whom 720 were Silesian penitentiary system inmates, and 177 were homeless. BACTEC MGIT fast TB detection system and GenoType Mycobacteria Direct test were used. Drug susceptibility testing was done using SIRE KIT and PZA KIT.

Results: Tuberculosis was diagnosed in 13 out of 897 persons (1.45\%): in 11 out of 720 inmates (1.53\%) and in 2 out of 177 homeless persons (1.13\%). Data concerning drug susceptibility were obtained for 11 persons. M. tuberculosis strains isolated from eight persons were susceptible to four first-line antituberculosis drugs (streptomycin, isoniazid, rifampin, ethambutol), while M. tuberculosis strains isolated from three persons were drug-resistant. One out of three isolated strains was resistant to ethambutol, but susceptible to streptomycin, isoniazid, rifampin, and pirazynamide. The second strain was resistant to streptomycin and pyrazinamide but susceptible to isoniazid, rifampin, and ethambutol. The third strain was susceptible to rifampin but resistant to the other four tested drugs.

According to the obtained data, culture-positive pulmonary tuberculosis was 100 times more frequent in the examined population than in the general population of the Silesia region in the same period of time.

Conclusions: The health project enabled effective detection of tuberculosis in risk groups and should be continued in the following years. The set of the applied diagnostic methods allowed the detection of in the studied subpopulations people suffering from tuberculosis. Patients were treated with antituberculosis drugs that would stop them from spreading the disease to other people.
\end{abstract}

Key words: tuberculosis, diagnostics, drug sensitivity testing, prisoners, homeless, Silesia region

Pneumonol. Alergol. Pol. 2015; 83: 23-29

Address for correspondence: Joanna Pendzich, MD, Pracownia Bakteriologii i Gruźlicy, SPSK nr 1, ul. 3-go Maja 13-15, 41-800 Zabrze, tel.: + 4832 373 22 52,

e-mail: jbpen@wp.pl.

DOI: 10.5603/PiAP.2015.0003

Received: 31.07 .2013

Copyright (C) 2015 PTChP

ISSN 0867-7077 


\section{Streszczenie}

Wstęp: W skali globalnej w więzieniach przebywa równocześnie więcej niż 10 milionów osób. Częstość występowania gruźlicy u więźniów jest 10-100 razy wyższa niż w ogólnej populacji. Osadzeni kontaktują się pomiędzy sobą oraz z pracownikami i odwiedzającymi, co stwarza ryzyko zarażenia ich gruźlicą. Po odbyciu kary więźniowie mogą być źródłem gruźlicy dla osób z otoczenia. Celem pracy było określenie częstości występowania aktywnej gruźlicy u osób bezdomnych, aresztantów i więźniów w województwie śląskim.

Materiał metody: Badaniami objęto 897 osób, w tym 177 podopiecznych Miejskiego Ośrodka Pomocy Społecznej (MOPS) i 720 osadzonych w zakładach penitencjarnych. W diagnostyce gruźlicy wykorzystano metody: BACTEC MGIT, MGIT TBc Identification Test i GenoType Mycobacteria Direct. Do określenia lekooporności prątków zastosowano zestawy SIRE KIT i PZA KIT.

Wyniki: Gruźlicę rozpoznano u 13 spośród 897 osób (1,45\%): u jedenastu osób na 720 (1,53\%) osadzonych w śląskich zakładach penitencjarnych oraz u dwóch osób na 177 (1,13\%) podopiecznych MOPS. Dane dotyczące lekooporności szczepów uzyskano w 11 przypadkach. Szczepy prątków gruźlicy wyhodowane od ośmiu chorych były wrażliwe na podstawowe leki przeciwprątkowe (streptomycyna, izoniazyd, rifampicyna, etambutol), natomiast trzy szczepy uzyskane od kolejnych chorych były oporne na leki: jeden — na etambutol, drugi — na streptomycynę i pirazynamid, a trzeci — na izoniazyd i etambutol.

Uzyskane dane przemawiają za tym, że częstość gruźlicy płuc potwierdzonej badaniem bakteriologicznym była w badanej grupie osób 100 razy wyższa niż w populacji województwa śląskiego w tym samym okresie czasu.

Wnioski: Realizowany program zdrowotny pozwala na efektywne wykrywanie przypadków gruźlicy w grupach ryzyka i dlatego powinien być kontynuowany w kolejnych latach. Zastosowany zestaw diagnostycznych metod laboratoryjnych umożliwił wykrycie w badanych subpopulacjach osób chorych na gruźlice. Chorzy zostali poddani leczeniu przeciwprątkowemu, co zatrzyma dalsze rozprzestrzenianie się zakażenia za ich pośrednictwem.

Słowa kluczowe: gruźlica, diagnostyka, lekooporność, więźniowie, bezdomni, województwo śląskie

Pneumonol. Alergol. Pol. 2015; 83: 23-29

\section{Introduction}

Tuberculosis (TB) has remained one of the most crucial health and social problems for more than two hundred years. The risk factors of disease are: malnutrition, restricted access to health care centres, aging of the societies, homelessness, growing migration of people, HIV infection, and devastating addictions to drugs or alcohol [1-3]. It is believed that placing a person in prison constitutes a risk factor of tubercle bacilli infection [4]. According to a WHO report, the prevalence of infectious diseases among inmates is 10 to 100 times higher than in the general population, which also applies to active TB, including multidrug-resistant TB [5]. Crowded prisons [6], insufficient ventilation of rooms, frequent rotation of inmates within the penitentiary and between the institutions are favourable conditions for transmission of TB [7-11].

The population of inmates consists mainly of poorly educated young males coming from dysfunctional families with high incidence of TB [12]. At the moment of admission to prison, convicts are often infected and are more prone to the development of active TB than the general population [13].

On a global scale, there are over 10 million prisoners worldwide [7]. It is estimated that there are 145 inmates per 100,000 people [7, 14]. According to the WHO, in 1998 in Poland the prevalen- ce of TB among prisoners was 153/100,000 [7]. According to Polish data, in 2008 the prevalence of TB in prisoners amounted to $270 / 100,000$, i.e. 10 times higher than in the general population [15]. Many reports have shown that the penitentiary system is a reservoir of $M$. tuberculosis [16-21]. It is difficult to compare the prevalence of TB between the general population and the inmates population as data concerning infected inmates are not easily available. In many countries such information is documented rarely or only in selected penal institutions [15, 22]. An impressive number of published reports on TB in inmates comes from the USA [23]. Prison officers who have developed active disease due to exposure to mycobacteria at work may infect other people in their environment. An American study in 2003 presented the results of research conducted in New York penitentiaries. It transpired that one-third of all TB cases concerned prison officers [17]. Whereas a study from 1997 showed that 38 inmates and 5 prison officers were infected with the same strain of tubercle bacilli [18]. To control the disease, it is necessary to make a quick diagnosis and apply a therapy. Failure to give a proper diagnosis or to use effective treatment may lead to the transmission of the disease to people from outside the prison, via infected staff, people visiting the inmates, or those who have already served their time [24, 25]. 
The published data have shown that the majority of correctional and detention facilities operate in such a way as to maximise public safety, and not to minimise the risk of transmission of a disease and to assure effective medical care to inmates [26]. The transfer of prisoners from one institution to another hinders diagnosis of $\mathrm{TB}$, monitoring of treatment results, and elimination of the disease [26].

Molecular testing has confirmed that transmission of TB between prisons significantly influences the incidence of TB among the population of inmates [27-29]. The health of prisoners is a vital element of public health [30].

Higher incidence of TB in correctional facilities, mines, and hospitals may lead to the spread of the disease in the whole population. Therefore, the mentioned institutions have been called "institutional amplifiers" of TB [31, 32].

In many countries, activities have been undertaken with the aim of preventing TB development in penitentiaries. In Israel, researchers have recommended completing of a symptom questionnaire by all new inmates, and a tuberculin skin test (TST) for prisoners infected with HIV, drug addicts, and immigrants from the former Soviet Union [16, 33]. They also recommend checking for TST in prison officers, and then completing a symptom questionnaire after one year of employment. The best time to diagnose and treat $\mathrm{TB}$ in inmates is the moment of entering the prison $[16,33]$. In order to reduce the incidence of $\mathrm{TB}$ in prisons, the analysis of two basic objectives (phases) of the disease control: early identification of persons with TB and effective application of DOTS strategy (directly observed treatment short course), was carried out in Bolivia, Ecuador, and Paraguay in the prisons that gathered the highest number of male inmates in the given state [34].

The problems in the penitentiary health care system, poor living conditions, failure to coordinate national TB control programmes with the penitentiary health care system, and insufficient resources hinder pursuing appropriate actions aimed at prevention and treatment of TB [34]. In Brazil, it has been shown that the number of professional health care workers employed in the penitentiary system is insufficient to fulfil the inmates' right to healthcare [35]. Furthermore, medical workers in the penitentiary system have been underpaid and employed on short-term contracts, which results in fluctuation of the staff [35].

Additionally, in recent years in Brazil the number of inmates has grown dramatically, which has made prisons the places that favour transmission of infectious diseases such as TB and HIV [36].

The homeless are also more at risk of active TB development [3, 37-41]. It is caused by poor living conditions, poverty, malnutrition or starvation, avoidance or lack of the possibility of benefiting from healthcare services, unhygienic lifestyle, or alcohol addiction. According to some researchers, homelessness is one of the greatest risk factors for acquiring latent $\mathrm{TB}$ infection and active TB [38]. Such an opinion has been confirmed by the results of research conducted in many countries, among others in Canada [37], Israel [33], Italy [42, 43], and the USA [38, 39, 44]. The Polish study of Jagodziński et al. reviewed the documentation of 300 patients hospitalised between 2004 and 2006 on a male ward of the Mazovian Centre for Treatment of Lung Diseases and Tuberculosis in Otwock. In total, 74\% of sputum-positive patients hospitalised in the Mazowsze region were professionally inactive, $57 \%$ of them were unemployed, and $10 \%$ were homeless [40].

The objective of the present study was to identify TB in homeless charges of the Municipal Social Assistance Centre (MOPS, Miejski Ośrodek Pomocy Społecznej) and in detainees and inmates in the Silesia region.

\section{Material and methods}

Centres conducting microbiological tests. The tests were performed in Zabrze in the Laboratory of Tuberculosis Bacteriology, Independent Public Teaching Hospital No. 3, Medical University of Silesia in Katowice, in the Laboratory of Bacteriology, Hospital of Lung Diseases in Orzesze, and in the Laboratory of Bacteriology, Central Laboratory of the Regional Health Centre in Katowice.

Characteristics of the study groups. A total of 897 subjects entered the study, including 720 detainees from five Silesian detention facilities (in Bielsko-Biała, Katowice, Mysłowice, Sosnowiec, and Zabrze), and from two correctional facilities (in Jastrzębie Zdrój and Zabrze) and 177 charges of the Municipal Social Assistance Centre (MOPS) in Katowice (4 local points in the city).

We examined the persons who were serving their sentence in the penitentiary or staying in MOPS (not at the moment of their admission to the mentioned institutions). The main idea of the project was to conduct microbiological TB tests in as many inmates and charges of MOPS as 
possible. Sputum samples were collected between September and November, 2012.

Selected subpopulations were described in respect of age and sex. Information about 877 subjects was obtained, representing $97.8 \%$ of the examined population. Men made up $88.5 \%$ of the study group, whereas women made up $11.5 \%$ (Table 1).

The study subjects ranged in age from 16 to 84 years, and the mean age was 39.83 years (Table 2). The subjects from correctional and detention facilities were younger (37.77 years) than the charges of the MOPS centres - the mean age in this subpopulation amounted to 49.01 years.

The study subjects were qualified for the examination by medical services from their home institutions, i.e. detention and correctional facilities (under the direction of the Chief Physician of the Regional Inspectorate of Prison Officers (OISW, Okręgowy Inspektorat Służby Więziennej) in Katowice) and MOPS in Katowice. The medical services of the institutions participating in the project (Municipal Social Assistance Centre, correctional/detention facility) took part in collecting sputum samples and preparing the list of the examined subjects, and in cases when TB was diagnosed their charges were sent for specialised treatment.

We applied five basic diagnostic methods that were appropriate for the clinical material,

Table 1. Sex structure of the studied population

\begin{tabular}{lccc}
\hline \multirow{2}{*}{ Institution } & \multicolumn{3}{c}{ Number of persons } \\
\cline { 2 - 4 } & Women & Men & Total \\
\hline Penitentiary/Prison & 54 & 662 & 716 \\
Municipal Social Assistance & 47 & 114 & 161 \\
Centre/Homeless shelters & & & \\
Total & 101 & 776 & $877^{*}$ \\
\hline
\end{tabular}

*Data about sex were obtained for 877 persons $(97.8 \%)$ out of the 897 examined subjects the stage of the research, the diagnostic objective, the and technical possibilities of the centres participating in the project.

Collected sputa were decontaminated by the NALC/NaOH method. From each decontaminated sputum two microscopic specimens were made, which then underwent direct Ziehl-Neelsen staining; cultures on solid media (classic method) and liquid media (rapid method) were performed. In the case of a positive result of a direct test and in clinically justified cases, DNA or RNA (depending on the equipment of the laboratory) were isolated, and a genetic method allowing the identification of $M$. tuberculosis in the clinical material was used.

In the case of identification of tubercle bacilli in the clinical material, the drug susceptibility of the cultured strains was assessed.

Based on the obtained drug susceptibility, antituberculosis chemotherapy was introduced.

Every identified case of TB was reported to the relevant medical services (MOPS, correctional/detention facility) and relevant Regional Sanitary-Epidemiological Station. The subjects suffering from the disease were hospitalised and treated in specialised healthcare centres.

\section{Results}

Tubercle bacilli were found in the clinical material collected from 13 out of 897 subjects included in the project (1.45\%).

M. tuberculosis colonies have been cultured from the clinical material collected from 13 persons, in whom mycobacteria were first found using methods other than culture. Using BACTEC MGIT system and/or classic method of solid culture, colonies of tubercle bacilli were obtained from sputum collected in 11 men out of 707 inmates from correctional/detention facilities $(1.53 \%)$ and from sputum of 2 men out of 177 examined charges of the MOPS (1.13\%) (Tables 3, 4). The obtained positive results of the

\section{Table 2. Age structure of the studied population}

\begin{tabular}{cccc}
\hline Statistical indicator/Institution & Penitentiary/Prison & $\begin{array}{c}\text { Municipal Social Assistance Centre/ } \\
\text { /Homeless shelters }\end{array}$ & Total \\
\hline Arithmetic mean & 37.77 & 49.01 & $39.83^{*}$ \\
Standard deviation & 12.25 & 14.25 & 13.36 \\
Minimum & 16 & 18 & 16 \\
Maximum & 72 & 84 & 84 \\
\hline
\end{tabular}

*Data about age were obtained for 877 persons (97.8\%) out of the 897 examined subjects 
Table 3. Results of diagnostic tests depending on the applied method

\begin{tabular}{lccc}
\hline \multicolumn{1}{c}{ Methods } & \multicolumn{1}{c}{ Results } & Total \\
\cline { 2 - 4 } & Positive & Negative & $884(93.35 \%)^{* *}$ \\
\hline Culture & $13\left(1.37 \%^{*}\right)$ & $871(91.98 \%)$ & \\
Susceptibility testing & & $11(1.16 \%)$ & $52(5.49 \%)$ \\
Genetic tests - DNA, RNA & $9(0.95 \%)$ & $43(4.54 \%)$ & \\
Total number of analyses & & $947(100 \%)$ & \\
\hline
\end{tabular}

*Percentage of total number of analyses

**Data about the results of 884 cultures were obtained

Table 4. Results of diagnostics performed using cultures and genetic methods in the studied subpopulations

\begin{tabular}{|c|c|c|c|c|c|c|}
\hline \multirow[t]{2}{*}{ Results/Methods } & \multicolumn{3}{|c|}{ Penitentiary/Prison } & \multicolumn{3}{|c|}{$\begin{array}{l}\text { Municipal Social Assistance Centre/ } \\
\text { /Homeless shelters }\end{array}$} \\
\hline & Positive & Negative & Total & Positive & Negative & Total \\
\hline Culture & $11^{*}\left(1.40 \%^{* *}\right)$ & $696(88.21 \%)$ & $707^{* * *}(89.61 \%)$ & $2(1.11 \%)$ & $175(97.22 \%)$ & $177^{* * *}(98.33 \%)$ \\
\hline Genetic tests - DNA, RNA & $9(1.14 \%)$ & $43(5.45 \%)$ & $52(6.59 \%)$ & - & - & - \\
\hline
\end{tabular}

culture were verified by other methods (e.g. MGIT TBc Identification Test, niacin test, GenoType Mycobacteria Direct). Drug susceptibility of isolated tubercle bacilli strains was assessed in 11 patients. Eight strains were susceptible to basic anti-TB drugs (SIRE, PZA). Among three strains of tubercle bacilli that were resistant to one or more first-line anti-TB drugs, one strain was resistant to ethambutol, one strain - to streptomycin and pyrazinamide, and one strain — to all tested drugs apart from rifampicin.

\section{Discussion}

The frequency of active TB in inmates is usually several or several-dozen times higher than in the general population, both in developing and developed countries [45-48]. In some regions of the world the situation may deteriorate [49]. In Europe and Central Asia, a relation between increased number of prisoners, TB incidence, and multi-drug resistant TB (MDR TB) has been shown [49].

According to the Bulletin of the National Institute of Tuberculosis and Lung Diseases, the number of patients diagnosed with all forms of TB in Poland in 2012, i.e. during the project, was 7542, with the incidence rate of 19.6 per 100,000 [50]. 5070 cases of TB were bacteriologically confirmed (an incidence rate of $13.2 / 100,000$ ). In the same year in the Silesia region, the number of patients diagnosed with of all forms of TB amounted to 1185 , with an incidence rate of 25.6/100,000. 759 cases were confirmed bacteriologically (an incidence rate of $16.4 / 100,000)$.

The incidence rate of TB for the populations of inmates and homeless people taking part in the project, calculated basing on the obtained results of the present study, was markedly higher compared to the respective coefficients for the state and the region (Table 5).

The objective of the study was to identify subjects with pulmonary TB. In Poland in 2012, the number of patients registered with pulmonary TB was 7018, the incidence rate was 18.2/100,000 [50]. Of these, 4870 cases were bacteriologically confirmed (an incidence rate of 12.6/100,000). According to the results of the present study, prisoners and charges of MOPS with active pulmonary TB represented $1.45 \%$ of the examined population; the incidence rate of active pulmonary TB was 1449 per 100,000: 1527/100 000 in prisoners and 1129.9/100 000 in the charges of MOPS. Tubercle bacilli were cultured exclusively from sputum collected from men. Tubercle bacilli were not cultured in any of the 101 examined women. This observation is in accordance with the data from the Institute of Tuberculosis, which has confirmed that the incidence of TB is higher in men than it is in women [50]. Assuming that 
Table 5. Tuberculosis cases and tuberculosis notification rates in the groups of people studied in 2012. Rates per 100,000 population

\begin{tabular}{lccc}
\hline \multicolumn{1}{c}{ Groups } & Number of studied persons & Number of TB cases & Tuberculosis notification rates \\
\hline Penitentiary/Prison & 720 & 11 & 1527.78 \\
$\begin{array}{l}\text { Municipal Social Assistance Centre/ } \\
\text { /Homeless shelters }\end{array}$ & 177 & 2 & 1129.94 \\
Total & 897 & 13 & 1449.2 \\
\hline
\end{tabular}

every undiagnosed and untreated person infects 9 healthy people (in the case of inmates: in prison, and after release from the prison among the general population), it should be stated that identification of 13 infected and sputum positive individuals is a remarkable achievement that has markedly decreased the probability of transmission of the disease.

During the WHO conference on TB and HIV infection in Europe, one of the main issues was a unified strategy for treating the diseases [51, 52]. One of the recent review articles from PLoS ONE has given a lot of information about the efforts made by the WHO and other organisations and services to combat TB in prisons [21]. It has published precise instructions on how to control and prevent TB in correctional facilities [21]. In Poland, guidelines for diagnosing and controlling TB are periodically published by the Polish Society of Lung Diseases [53]. The National TB Reference Laboratory in Warsaw controls periodically subordinated laboratories regarding the quality of performed tests for TB. Local institutions of different rank draw up and introduce projects such as regional TB control programmes to prevent active TB development among the most threatened social groups.

\section{Conclusions}

Tests for active $M$. tuberculosis infection conducted in the Silesia region in a group of 177 charges of the Municipal Social Assistance Centre and 720 inmates and detainees have allowed the identification of 13 persons with TB, including 2 homeless people and 11 inmates. The applied set of laboratory diagnostic methods enabled effective identification of persons with active TB. The persons infected have undergone antituberculosis treatment, which has prevented further spread of the disease. The obtained results have shown the urgent need for further studies in the groups that are particularly exposed to TB.

\section{Acknowledgements}

The authors would like to thank:

Marek Piekarski MA, Deputy Director of the Faculty of Health and Social Policy of the Silesian Marshal Office

Michał Lorek MA, Regional Tuberculosis Control Programme Coordinator

Jarosław Malik MA, Manager of the Department of Social Policy and Health Promotion, Medical University

Aniela Wlizło MA, Head of SPSK-3, Medical University of Silesia in Zabrze

Lt. Col. Andrzej Sikora, Head of the Correctional Facility in Zabrze

Rafał Barczak PhD, Chief Physician, Regional Inspectorate of Prison Services in Katowice

The staff of correctional and detention facilities and Social Assistance Centres that participated in the project

\section{Conflict of interest}

The authors declare no conflict of interest.

\section{References}

1. Murray J.F. La tuberculosis dans le monde: situation et perspectives en l'an 2001. Rev. Mal. Respir. 2001; 18: 479-483.

2. Tignor M.M. Socioeconomic factors in tuberculosis. N. Engl. J. Med. 1981; 304: 431-432.

3. Emmanuelli X., Grosset J. Tuberculose et pauvreté. Rev. Mal. Respir. 2003; 20: 169-171.

4. Bellin E.Y., Fletcher D.D., Safyer S.M. Association of tuberculosis infection with increased time in or admission to the New York City jail system. JAMA 1993; 269: 2228-2231.

5. Van't Hoff G., Fedosejewa R., Mihailescu L. Prisons preparedness for pandemic flu and the ethical issues. Public Health 2009; 123: 422-425.

6. Coninx R., Maher D., Reyes H. et al. Tuberculosis in prisons in countries of high prevalence. BMJ 2000; 320: 440-442.

7. World Health Organization. Tuberculosis control in prisons. A manual for program managers. WHO/CDS/TB/2001.281. Geneva 2000.

8. Lobacheva T., Asikainen T., Giesecke J. Risk factors for developing tuberculosis in remand prisons in St. Petersburg, Russia — a case-control study. Eur. J. Epidemiol. 2007; 22: 121-127.

9. Banu S., Hossain A., Uddin M.K. et al. Pulmonary tuberculosis and drug resistance in Dhaka central jail, the largest prison in Bangladesh. PLoS ONE 2010; 21: e10759. 
10. Abebe D.S., Bjune G., Ameni G. et al. Prevalence of pulmonary tuberculosis and associated risk factors in eastern Ethiopian prisons. Int. J. Tuberc. Lung Dis. 2011; 15: 668-673.

11. Todrys K.W., Amon J.J., Malembeka G. et al. Imprisoned and imperiled: access to HIV and TB prevention and treatment and denial of human rights, in Zambian prisons. J. Int. AIDS Soc. 2011; 14: 8. doi: 10.1186/1758-2652-14-8.

12. March F., Coll P., Guerrero R. et al. Predictors of tuberculosis transmission in prisons: an analysis using conventional and molecular methods. AIDS 2000; 14: 525-535.

13. Dara M., Grzemska M., Kimerling M.E. et al. Guidelines for control of tuberculosis in prisons. 2009. Available from: pdf. usaid.gov/pdf docs/PNADP462.pdf.

14. Fazel S., Baillargeon J. The health of prisoners. The Lancet 2011; 377: 956-965.

15. Brzezińska S., Zabost A., Kozińska M. et al. Molecular analysis of strains from tuberculosis patients in Polish prisons in 2004-2008. Initial analysis of the project. Pneumonol. Alergol. Pol. 2012; 80: 209-213.

16. Grzemska D.M., Coninx R., Reyes H.Guidelines for the control of tuberculosis in prisons. WHO/TB/98.250. Geneva: World Health Organization, 1998.

17. Jones T.F., Charles L.W., Francis F. Increased incidence of the outbreak strain of Mycobacterium tuberculosis in the surrounding community after an outbreak in a jail. South Med. J. 2003; 96: 155-157.

18. Chaves F., Dronda F., Cave M.D. et al. A longitudinal study of transmission of tuberculosis in a large prison population. Am. J. Resp. Crit. Care Med. 1997; 155: 719-725.

19. Hammett T.M., Harmon M.P., Rhodes W. The burden of infectious disease among inmates of and releases from US correctional facilities, 1997. Am. J. Public Health 2002; 92:1789-1794.

20. Abrahão R.M., Nogueira P.A., Malucelli M.I. Tuberculosis in county jail prisoners in the western sector of the city of São Paulo, Brazil. Int. J. Tuberc. Lung Dis. 2006; 10: 203-208.

21. Legrand J., Sanchez A., Le Pont F. et al. Modeling the impact of tuberculosis control strategies in highly endemic overcrowded prisons. PLoS ONE 2008; 3: 2100

22. Portales F., Rigouts L., Bastian I. Adressing multidrug-resistant tuberculosis in penitentiary hospitals and in the general population of the former Soviet Union. Int. J. Tuberc. Lung Dis. 1999; 3: $582-588$

23. Jones T.F., Craig A.S., Valway S.E. et al. Transmission of tuberculosis in jail. Ann. Intern. Med. 1999; 131: 557-563.

24. Mitchell C.S., Gershon R.M., Lears M.K. et al. Risk of tuberculosis in correctional health care workers. J. Occup. Environ. Med. 2005; 47: 580-586.

25. Cone J.E., Harrison R., Katz E. et al. Tuberculosis transmission to prison employees during an outbreak among prisoners at two California prisons. J. Health Safety 2000; 4: 75-79.

26. Bick J.A. Infection control in jails and prisons. Clin. Infect. Dis. 2007; 45: 1047-1055.

27. Clark P.A., Cegielski J.P., Hassell W. TB or not TB? Increasing door-to-door response to screening. Public Health Nurs. 1997; 14: $268-271$

28. Ijaz K., Yang Z., Templeton G. et al. Persistence of a strain of Mycobacterium tuberculosis in a prison system. Int. J. Tub. Lung Dis. 2004; 8: 994-1000.

29. Kuhleis D., Wolowski Ribeiro A., Dalla Costa E.R. et al. Tuberculosis in a southern Brazilian prison. Mem. Inst. Oswaldo Cruz, Rio de Janeiro 2012; 107: 909-915.

30. Gois S.M., De Oliveira Santos Junior H.P., de Fatima M. et al. Beyond bars and punishment: a systematic review of prison health. Cien. Saude Colet. 2012, 17: 1235-1246.

31. Basu S., Stuckler D., McKee M. Addressing institutional amplifiers in the dynamics and control of tuberculosis epidemics. Am. J. Trop. Med. Hyg. 2011; 84: 30-37.

32. Tuberculosis, Data and Statistics, http://www.cdc.gov/tb/statistics/default.htm.

33. Mor Z., Adler A., Leventhal A. et al. Tuberculosis behind bars in Israel: Policy making within a dynamic situation. IMAJ 2008; 10: 202-205.
34. Waisbord S. Participatory communication for tuberculosis control in prisons in Bolivia, Ecuador, and Paraguay. Rev. Panam. Salud Publica 2010; 27: 168-174.

35. Sánchez A.R., Diuana V., Larouzé B. Tuberculosis control in Brazilian prisons: new approaches to an old problem. Cad. Saúde Pública, Rio de Janeiro 2010; 27: 850-851.

36. Baptista I.M., Oelemann M.C., Opromolla D.V. et al. Drug resistance and genotypes of strains of Mycobacterium tuberculosis isolated from human immunodeficiency virusinfected and non-infected tuberculosis patients in Bauru, São Paulo, Brazil. Mem. Inst. Oswaldo Cruz 2002; 97:1147-1152.

37. Khan K., Rea E., McDermaid C. et al. Active Tuberculosis among Homeless Persons, Toronto, Ontario, Canada, 19982007. Emerg. Infect. Dis. 2011; 17: 357-365.

38. Higgs B.W., Mohtashemi M., Grinsdale J. et al. Early detection of tuberculosis outbreaks among the San Francisco homeless: Trade-offs between spatial resolution and temporal scale. PLoS ONE 2007; 12: 1284-1292.

39. McAdam J.M., Bucher S.J., Brickner P.W. et al. Latent tuberculosis and active tuberculosis disease rates among the homeless, New York, New York, USA, 1992-2006. Emerg. Infect. Dis. 2009; 15: 1109-1111.

40. Jagodziński J., Zielonka T.M., Błachnio M. Status społeczno-ekonomiczny i czas trwania objawów u mężczyzn chorych na gruźlice leczonych w Mazowieckim Centrum Leczenia Chorób Płuc i Gruźlicy w Otwocku. Pneumonol. Alergol. Pol. 2012; 80: 533-540.

41. DeVries G., VanHest R.A. From contact investigation to tuberculosis screening of drug addicts and homeless persons in Rotterdam. Eur. J. Public Health 2006; 16: 133-136.

42. Ministry of Health Italy, November, 2009; http://www.salute.gov.it/imgs/C 17 pubblicazioni 613 allegato.pdf; Ministry of Health Italy, Rapporto La tubercolosi in Italia anno 2008 , http://www.salute.gov.it/imgs/C 17 pubblicazioni 1222 allegato.pdf; Epicentro Istituto Superiore di Sanit`a, http://www. epicentro .iss.it/problemi/Tubercolosi/epid.asp.

43. http://www.roma-capitale.it/documenti/ laquartacapitale.pdf

44. The World Health Report 2004 - changing history. World Health Organization, WHO 2004.

45. Öngen G., Börekçi S., İçmeli Ö.S. et al. Pulmonary tuberculosis incidence in Turkish prisons: importance of screening and case finding strategies. Tuberk. Toraks 2013; 61: 21-27.

46. Bone A., Aerts A., Grzemska M. et al. Tuberculosis control in prisons: a manual for programme managers. 2000; Geneva: World Health Organization.

47. MacNeil J.R., Lobato M.N., Moore M. An unanswered health disparity: tuberculosis among correctional inmates, 1993 through 2003. Am. J. Public Health 2005; 1: 1800-1805.

48. Coninx R., Eshaya-Chauvin B., Reyes H. Tuberculosis in prisons. Lancet 1995; 346: 1238-1239.

49. Stuckler D., Basu S., McKee M. et al. Mass incarceration can explain population increases in TB and multidrug-resistant TB in European and central Asian countries. Proc. Natl. Acad. Sci. USA 2008; 105: 13280-13285.

50. Gruźlica w Polsce. Biuletyn IgiChP — 2014 r. Stan na wrzesień 2014r.; http://www.igichp.edu.pl/

51. [No author listed] Accelerating the implementation of collaborative TB/HIV activities in the WHO European Region 16-17 July 2010, Vienna Austria, Available at: http://www.stoptb.org/ wg/tb_hiv/assets/documents/agenda2.pdf.

52. WHO 2000. Tuberculosis control in prisons. WHO/CDS TB/2001/.281. Geneva: WHO. Available at: http://www.who.int/ tb/publications/prisons_tb_control_manual/en/index.html. Centers for Disease Control and Prevention (CDC), National Center for HIV/AIDS, Viral Hepatitis, STD, and TB Prevention. Prevention and control of tuberculosis in correctional and detention facilities: Recommendations from CDC. MMWR Recomm Rep 2006; 55: 1-44. Available at: http://www. cdc.gov/mmwr/preview/mmwrhtml/rr5509a1. htm.

53. Augustynowicz-Kopeć E., Demkow U., Grzelewska-Rzymowska I. et al. Zalecenia Polskiego Towarzystwa Chorób Płuc dotyczące rozpoznawania, leczenia i zapobiegania gruźlicy u dorosłych i dzieci. Pneumonol. Alergol. Pol. 2013; 81: 327-379. 